\title{
Vañcaikka!̣am Past and Present Rāmāyaṇa Panels in Kēraḷa-Mahādeva Temple
}

\author{
R.K.K. Rajarajan
}

Gandhigram Rural University, India

\begin{abstract}
Vañcaikkaḷam is a Śiva-sthala in the Kuțtanāḍu region of Kēraḷa. It is one among the \pm 280 sthalas extolled in the Têväram (7.4) hymns. Noted for the typical Kerrala temple-type, it is unique in several respects. Saints Cēramān Perumāl and Cuntarar are associated with the venue, and they are supposed to have visited the Kailāsa on the Himālayas in person, a rare honour that Śiva confers on the Nāyanmār. This may be a metaphor for considering Vañcaikkalam as the Śiva-loka on earth or the Dakșina-Kailāsa. Research on the architecture and iconography of the temple is scanty excepting the tidbits in Sarkar 1978 and Paramesvaran Pillai 1986. The present article presents an account of the temple from literature, and fieldbased study of architecture and iconography with special reference to the rare Rāmāyana wood-carved sculptures.

Keywords: Vañcaikkaḷam/Vañchikkuḷam, Vañci, Śrīkōvil, Cēramān Perumāl, Cuntarar, Tēvāram, Tirukayilāyañānaulā, Rāmāyaṇa, Rāmāṣṭottaram, Rāma, Viśvāmitra, Paśupati, Dakṣiṇāmūrti, Kailāsa, wood-carved images.
\end{abstract}


Vañcaikkaḷm (Malaiyāḷam Vañchikkuḷam) is a famous Śiva-sthala in the Kutțanādu (Lowlands) region of Central Kērala. Saint Cuntarar, a contemporary of Cēramān Perumāḷ c. 800 CE (TAS II-I: 8-14, Sarkar 1978: 21,59 ) has composed a patikam (collection of ten hymns) on the venue. The sthala is one among the +280 (Spencer 1970: 232-44, Kalidos 2006: II, 292) listed from the hymns of the Tevearram-trio (Sathyanathaier 1980: 408) ${ }^{1}$. The venue has been identified with the metropolis of the ancient Cēras, Vañci (Sarkar 1978: 13), and where Cenkuuțuvan of Patirruppattu ( $5^{\text {th }}$ Ten, Patikam) and Cilappatikāram fame erected a temple for Pattini-Kaṇnaki (Rajarajan 2014: chap. V). The temple for Bhagavatī-Kaṇnaki of Koțunkallūr ${ }^{2}$ is about a km from the Mahādeva at Vañcaikkaḷam. Of the two temples, Koṭunkallūr seems to be the earliest. The existing temple for Pattini (also Bhadrakālī) is likely to have been erected on the debris of an early structure built by Cenkuttuvan (c. $150 \mathrm{CE}$ ), and dated since the sixteenth century CE. Vañcaikkalam emerges into the picture as a center of Sivaism (Gonda 1970) by about the time of Cēramān Perumāl and Cuntarar in the early ninth century CE. The place-name is a pointer of its link with Vañci of the ancient Cèras. It has been the subject-matter of Cuntarar's patikam; cf. Kulacēkara Ālvār on the Viṣnu temples in Kēraḷa ${ }^{3}$. It is not clear why Cēramān Perumāl Nāyanāar is silent about the sthala-Vañcaikkaḷm ${ }^{4}$. He was a devoted

${ }^{1}$ The three are Nāanacampantar, Nāvukkaracar and Cuntarar (seventh-ninth centuries $\mathrm{CE}$ ). Other sources list a total of 274 sthalas (vide, temple.dinamalar.com). Vañcaikkaḷm is the only Siva-sthala in Kerala extolled in bhakti hymns (Têvāram 7, Patikam 4).

${ }^{2}$ The structure of the temple and the rituals has undergone thorough ramifications during the past millennium and a half (Gentes 1992, cf. Rajarajan \& Jeyapriya 2014: chap. V).

${ }^{3}$ The Vaișnava hymnist, Kulacēkara Ālvār has composed the Perumāl Tirumoli in about 100 hymns that encompasses divyadeśas such as Arankam (cf. Kalidos 199395: 136-52, Jeyapriya 2001: 612-15, Rajarajan 2013: 70-71), Cittirakūțam (Kalidos 1997: 17-24), Vēnkațam (Jeyapriya 2014*), Kaṇ[ṇ]apuram (Kannan 2006: chap. I)**, and Vittuvakkōtu (modern Mițtakōẹē in Malaiyālam; vide, Rajarajan 2013a).

* Presents a brief summary of c. 200 Ālvārs' hymns. All the saints have contributed their share excepting Maturakavi and Tonțarațippoți.

** Presents a summary of 128 hymns.

${ }^{4}$ Cêramān Perumāl is credited with three works that come under the $11^{\text {th }}$ Tirumurai (Zvelebil 1974: 197-98). They are Ponvannnattiruvantāti-PTA (100+1 quatrains), Tiruvārūr-mummanikkōvai-TMK (29 poems in 11. 4 to 20) and TirukkailāyañānulāTKN (long poem in 11. 304). These works do not spell out Vañcaikkalam. Tillai [later Citamparam] (PTA 77), Ārūr (TMK 1, 8, 10, 16, 22) and Kațavūr (TMK 24) are 
Siva-bhakta and rāja-yogi that is attested by the TKN. His alleged conversion to Islam (Sastri 1971: 162) is due to Șuffi concoction of the post-ninth century ${ }^{5}$. Highly orthodox in ritual performances within the sacred precincts, temples in Kēraḷ were not accessible for field-based research until the last generation, and photography was and is in certain parts of temples strictly prohibited. Therefore, no illustrated account of the temples may be found in any published work, excepting a bird's eye view (see plates and plans in Kramrisch et al. 1970, Sarkar 1978, Noble 1981, Pillai 1986, Jayashanker 1997).

The present study brings to light a brief account of the Vañcaikkalam temple with special reference to the wood-carved Rammayana sculptures. It hopes to add to our existing knowledge on the temples of Kēraḷa. It may be of concern to scholars interested in Kēraḷ studies that are not permitted to enter the sacrosanct parts of the Hindu temples. The aim is three-pronged:

1. A brief description of the Vañcaikkalam temple (cf. Pillai 1986: 189)

2. Examination of the Rämāyana wood-carved images

3. A summary of the hymns bearing on Tiruvañcaikkalam (Attachment)

\section{The Temple}

The temple, called Mél-tali (Upper Temple) ${ }^{6}$ is east facing and is in two prākäras. Entry into the oblong temple is provided in the east and

notified. It is likely the Civalōkam, Civapuram and Tirukkōyil appearing in TKN 5 is a metaphor for Vañcaikkalam. Several sacred centers of worship in the south are considered Dakșina-Kailāsa (e.g. Tillai and Ārūr), and Vañcaikkaḷam is one among the choicest.

${ }^{5}$ Kēraḷa being midway between Rome and China was the meeting place of Semitic, Greek, Roman, Jew, Syrian Christian, Chinese (early settlements), Arabs (pre- and post-Islamic) from time immemorial. Conversion to the alien religions either voluntary or at the point of gun and Inquisition went on unabated (Kumar 2013: 2129). R.K.K. Rajarajan (2014: chap. V, note 14) reports a depressed community of Cērumānns (Thurston 1909: II see under Cheruman) has apparently disappeared from the anthropological map of Kērala due to conversions. Interestingly, Thurston 1909 cites Indian informants that say the Cerumānns (cf. Cēramānn) were the ancient Cēras.

${ }^{6}$ Kìltali and Méltali stand for temples on the lower and upper part of a venue; cf. Kacci-mērraḷi (Têvāram 4.62, 7.21) and Kuṭantaik-kīllkkōttam (ibid. 6.289). Taḷi and kōttam mean "temple". 
west by gopuras in the typical Kēralite mode. Both the inner and outer prākâra entrances accommodate gopuras that is supposed to be unique feature in Kêrala ${ }^{7}$. Pillai (1986: 169) adds the following note:

"Noted for its structural peculiarities, the most noteworthy feature is the presence of more than one gopuram. Srikovil [śrikōyil ${ }^{8}$ has a porch in front, a feature not commonly found in other temples. Numerous shrines are there within the sacred enclosure. The statues of Ceraman Perumal Nayanar [Cēramān Perumāl Nāyanāār] and his spiritual preceptor Sundaramurti Svamikal [Cuntaramūrti Cuvāmikal]] are set up and worshipped. In the temple precincts are found a pair of konna trees (Cassisus fistural [Tamil kongrai Cassia fistula])...Mural paintings... 100 sq. ft. (tenth and eleventh centuries) could be seen. Two Malayalam inscriptions... [of] Ravivarma, King of Cochin [Kocci], are dated 1801 and $1831 \ldots$ ". [Box parenthesis mine]

During a recent visit to the temple we were able to do some photographic job in the outer prākâra. A vast tank, kulam is found nearby after which the Malaiyālam place-name, Vañcaik-kulam takes $\operatorname{root}^{9}$. The Lord was known Añcaikkalattappan (see Attachment), Vañchuleśa (early $19^{\text {th }}$ century) and presently Mahādeva.

A brief account of the layout is presented hereunder to better understand and locate the Rammayana wooden sculptures that seem to have been added during the $17^{\text {th }}-18^{\text {th }}$ century. Casually it may note, the Ràmāyana sculptures from the wooden temple cars (Tamil têr, Sanskrit ratha) have received an adequate treatment (Kalidos 1988: 104 [figs. 1-10], 1989: 349-57, 1991: figs. 1-14, cf. Rajarajan 1998: 329-48 [figs. 1-20], cf. 2006: figs. 119-123, 231-233, 238, 2010: 101105 [figs. CP XIV-XVII 1-15]; Jeyapriya 2010: 113-16, figs. CP XIX.1-XXII-2). Raju Kalidos 1989 has registered 200+ wood-carved

\footnotetext{
${ }^{7}$ Massive räyagopuras at the cardinal directions appear in temples of Tamilnadu (Auboyer 1994: plans 1-2, Rajarajan 2006: II, pls. Maturai-1, Śrīrañgam-10; Rajarajan \& Jeyapriya 2013: pls. 1-2, cf. Harle 1963) reaching the apogee in Śīrangam. For early dwarf-gopuras, called dvāraśobha see Rajarajan 2012: figs. 14, 46-47).

${ }^{8}$ Cf. tirukkōyil in Tirukkailāyañānaulā [v. 5] of Cēramān Perumāla The author's name is Cērarkōmān (PTA 101) that is supposed to have travelled on a vellananai (white elephant) to the Kailāsa. This event is illustrated in the Cōla murals of the Rājarājeśvaram at Tañcāvūr (Sriraman 2011: figs. pp. 181-882).

${ }^{9}$ Kalam means "field", maybe also ksetra or sthala that appears in the hymns of Cuntarar (see Attachment). Kulam is "tank" or "water reservoir". The vast tank close to the temple seems to have been enlarged during the later medieval period that was originally a pond (cf. Cuntarar's hymns in Attachment).
} 
images on the subject (Dallapiccola 1994: 11-24, cf. Dallapiccola et al. 2005: 253-308, Kalidos 2006: II, pl. VIII). The present article demonstrates how the hidden temples of Kèrala open new avenues of research on Hindu iconography in general and the Rāmāyana imagery in particular. Sarkar 1973 and 1978 has not illustrated any wooden sculpture on the Rammayana theme ${ }^{10}$. Therefore, the present article is rewarding on Kērala studies and the Rāmāyana .

The temple is provided with entrances in the east and west on the outer and inner prākäras (Fig. 1, Plan). The entrance on the east is fitted with a Kērala-type gopura that is dvitala (Fig. 2) ${ }^{11}$. The outer wall on the west is fitted with a dvarraśobha (detailed in Kāyapaśilpaśástra and Mayamata chap. 24, Dagens 1985: 163; Ramakrishnan 1993-95: 91; Fig. 3). Tall gopuras appear on the entrances to the outer nạlambalam (Jayashanker 1997: pl. 13, Rajarajan 2014: figs. 5-6). The Brahmasthāna, i.e. śrīkōvill garbhagrha is encased in the inner sacred core of the temple. Spoken with reference to the majestic gopura on the east ${ }^{12}$, it could be presumed the main entrance to the temple is east ${ }^{13}$.

Entering the east gopura and moved in pradakșina chapels for Dakșināmūrti (south Fig. 4) and Paśupati (southwest Fig. 5) are viewed on the southern sector. The western sector provides for a dvāraśobahä-gopura and ānapandal "porch". On the northwest the well is found (Fig. 6). In between the porch and tank two more chapels are accommodated. The northern sector houses two konnai trees $^{14}$, hypaethral Linga and votive nāgas (Fig. 7). The interlaying

\footnotetext{
${ }^{10}$ A mural relating to the Pațāahbiṣeka of Rāma is inserted from the Pallimanna Śiva temple, Kumblanāọ (Sarkar 1978: pl. LIII.B). Very few wood-carvings are reported in this work. See illustrations in Sarkar 1973.

${ }^{11}$ Some try to find Chinese influence (see note 5) on the architecture of Kērala and at the same time admit it "is doubtful" (Mitter 2001:73, fig. 48).

${ }^{12}$ When we visited the temple sometime in January 2014, we proceeded from the Kaṇnaki-Bhagavatī temple through the main streets of the twin-city, VañcaikkuḷamKoțunkallūr, and were compelled to get into the complex by the western gateway.

${ }^{13}$ Gateways to Maturai and Srïrangam temples are found on four cardinal directions. However, in Srirangam the pilgrims usually get an access to the temple through the south. The popular entry points in the Mīnākṣi-Sundareśvara temple are east and south.

${ }^{14}$ Cêramān Perumāl in his hymns repeatedly notes the konrai (Cassia fistula), the favourite of Śiva (PTA 35, 39-40, 49-51, 63, 90; TMK 18). Cf. Cuntarar (Tēeāram 7.24.1) adds: Minnnār ceñcațaimēl miliirkonnrai yaṇintavanēe "glittering kongrai decks the shining tiara".
} 
space in between the two eastern gopuras is occupied by a porch; tall brick and mortar pillars fitted with a tiled superstructure. The dvajastambha, vāliyabalikal and agramandapa are affixed in this venue.

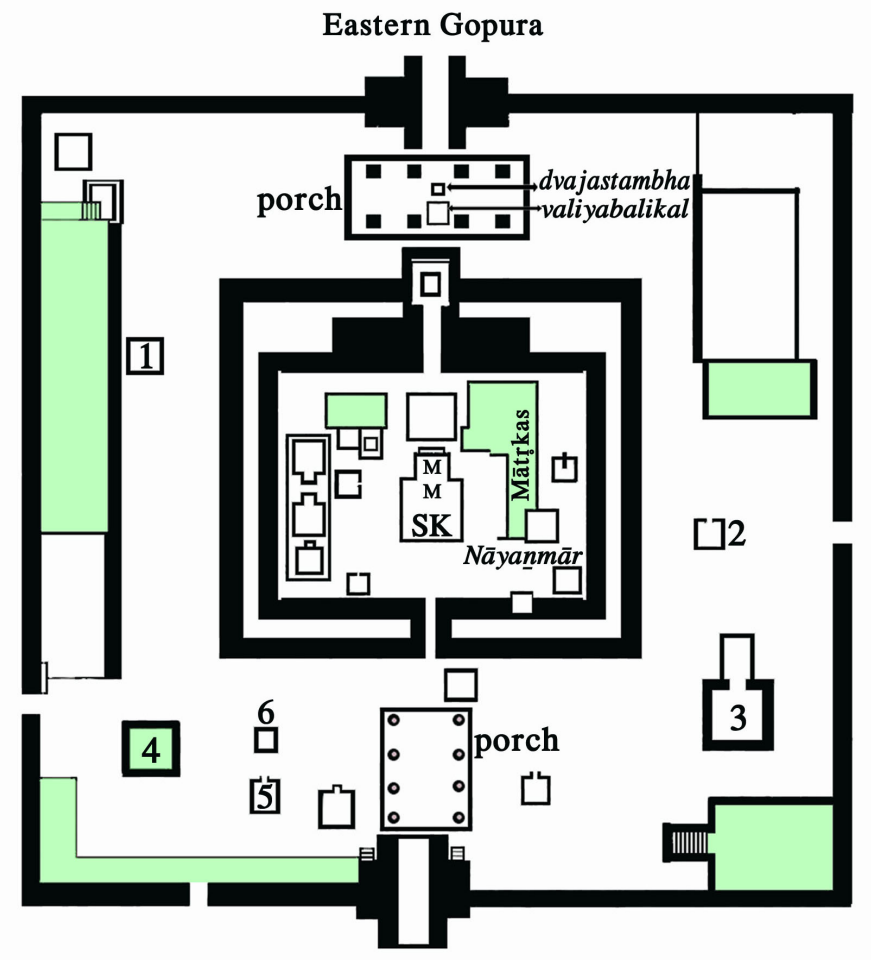

Approximate sketch of the Temple

\section{ŚK: ‘Śrīkōvil’}

MM: mukhamaṇḍapa

1. 'Konnai' trees, Linga and Nāgas

2. Dakṣināāmūrti

3. Paśupati

4. Well

5. Caṇdikeśvara

6. Upadevatās

Figure 1: Plan of the Mahādeva Temple, Vañcaikkaḷam 
The garbhagrha for Añcaikkalattappan-Mahādeva is located in the inner enclosure of the temple facing east (cf. Sarkar 1978: pls. LXXIII-LXXV). The images of Cuntarar and Cēramān Perumāl are installed in this sacred zone ${ }^{15}$. They are supposed to have moved to the Kailāsa, and so there is every reason to suggest the venue is the Dakșina-Kailāsa (supra). Furthermore, Cēramān Perumāl in TKN (11. 8-9) makes a note of Civalōkam (also PTA 5) ${ }^{16}$, Civapuram and Tirukkōyil (Malaiyāḷam Śrīkōvil) thereby suggesting Vañcaikkalam is the Kailāsa ${ }^{17}$. Maheśvara or Mahādeva and his abode in the Kailāsa

\footnotetext{
${ }^{15}$ Separate prathiștha of Sapta Mātrkas, Arupattumūvar (Nāyan̄mār-63), Națarāja, Caṇịikeśvara, Unnideva, and other upadevatās are present. Totally twenty-five such installations are identified.

${ }^{16}$ Cuntarar and Cēramān Perumāl are supposed to have visited the Śiva-loka with their mortal coil. Cf. Varaguna Pāṇ̣̂a taken to the Siva-loka (Tiruvilaiyāțar Purnam of Perumparrappuliyūr Nampi, Episode 48). Vide, Rajarajan \& Jeyapriya 2013: 7, 11, 33-34, fig. 66.

${ }^{17}$ The TKN visualizes the $u l \bar{a}$ "procession" of Śiva on the Kailāsa decorated with all royal paraphernalia and a host of attendant-gods*. The ula is meant for the darśana of women belonging to seven-age groups such as pètai 5-8 (age), petumpai 9-10, mankai 11-14, matantai 15-18, arivai 19-24, terivai 25-29 and perrilampen 30-36 (Zvelebil 1974: 199). Presumably, they are in love with Śiva (TKN 1. 85 notes Kämannūl/Kämasūtra?). In those times pre-puberty marriages (down to the early twentieth century) were common. Kaṇnaki was married at the age of twelve as mañkai (Cilappatikāram 1.24). Now-a-days, a woman getting married at the age of 30 as perilampen is common.

* They are Nanti (Nandi), Vacukkal (Vasus 8), Eluvar-Iruțikal (Sapta-Roșis), Panniruvar-Ātittar (Dvādaśa-Āditys), Akattiyan (Agastya), Yaman, Niruti-mutalōr (Nairrti, the dikapālakas - Wessels-Mevissen 2001: 98-100), Varuṇan, Vāyu, Cōman (Candra), Īcāñan, Accuñi (Aśvins), Tūya-Uruttirarkal (Pure Rudras), Kupēran (Kubera), Kañkai-Yamuñai...tìttañkal (Gañgā, Yamunā and other tīrthas), Nākametțu/Așta-Nāgas (Nāgas eight), Tumpuru-Nāratar (Tumburu-Nārada), Cēñāpati (Devasenāpati-Skanda), Intiran (Indra), Ayan (Brahmā), Karuṭan (Garuḍa), Kāmañ, Vāman (Arhat or the Buddha), Viāyakan, Mañkai-eluvar (Seven Mātrkas or Pattinis), Nīli riding lion, Viccātarar (Vidyadhara), Iyakkar (Yakṣa), Kinnnarar, Kimpuruțar, Kinkarar, Kaṇam (ganas), Arakkar-Acurar (demons), Vālakilyar (Valakhilyas) and so on. The TMK adds Nāyirnu/Sun (PTA 26), Tinkaḷ/Moom and Pāṃpu "snakes" (RāhuKetu? PTA 90), and Cevvāy/Mars (1. 5) an early vision of the Navagrahas, the Nine Planetary deities (cf. Tēvāram 2.221.1: Ñāyiru Tỉnkal Cevvāy Putan Viyālam Veḷ!ḷi Cani Pāmpirantu "two serpents"; Rajarajan 2006: 104, 2015:169-96). It is only in the hymns of Cēramān that such a cavalcade of minor gods is obtained, supposed to attend on the Cosmic Man, Purușa-Śiva who pervades through the celestial bodies in the Milky Way, Aṇtattukkappāḷn (TMK 4) as the Sthāṇu/Tāṇu "Pillar/Linga" (PTA 38), the Ādimūrti/Ātimūrtti "Primeval Lord" (TMK 10) on the Axis mundi, Mēru (PTA 88).
} 
are detailed in the Śivapañcākșarī (Śrītattvanidhi 1.3.1). The Lord in this account is presumably Paśupati ('Pacupati' PTA 30, 61 "Lord of Creatures") full of compassion for bhaktas. The two chapels for Paśupati ${ }^{18}$ and Dakșināmūrti ${ }^{19}$ in southern nālambalam would confirm the benign aspect of Śiva ${ }^{20}$. Siva's basic ethos is tâmasa, and thereby the God of Destruction (Jeyapriya 2009: chap. I). He is viewed as a sustaining principle in the Vañcaikkaḷam tradition; cf.TKN:

Ariyākik kāppān Ayañāyp pațaippān

Aranāy alippavanun tān̄ē...

Evvuruvil yāroruvar uḷuvar vuḷattu!

Avvuruvāyt tōñri aruḷkoțuppān̄... [11. 5-10]

"The protector as Hari, the creator as Brahmā

The destroyer as Hara, He is...

Whoever those imagine in whichever form appears in their mind

(The Lord in) such a design confers his grace..."

It is to suggest Śiva compresses Viṣnu and Brahmā within his own mega-personality as the Cosmic [Virāt-]Purușa (cf. the Purușasūkta of the Rgveda; Irukku in TKN 1. 24; Viśvarūpa in Śivasahasranāma 44, 95; Maxwell 1983: 213-34). Siva is supposed to be foremost among the Trimūrti:

Mēvarāya viraimalarōn̄ ceñkaṇmā līcannnennnum

\footnotetext{
${ }^{18}$ It stands to be verified whether independent chapels for Paśupati (cf. Lorenzetti 1996) exist elsewhere; the earliest imagery is of the Indic culture (Basham 1971: pl. $5 f)$.

${ }^{19}$ Dakșināmūrti normally appears in a devakostha in temples of Tamilnadu since the Pallava period, e.g. Takkōlam, Tiruttaṇi, Kalukkuñam, and Puḷamañkai (Kalidos 1996: fig. 8) and not in a separate chapel (Kalidos 2006: II, pl. LXXVII.2, cf. LXXVIII.1, CIV.1). Interestingly the Lord is muulabera in the Irunilañkọ̄u/Kērala rock-cut cave (Ibid. pl. CV, Sarkar 1978: pl. IV.B).

20 Dakṣiṇāmūrti (cf. the Dakṣināmūrti-stotra of Śankara) and Paśupati (Śivasahasranāma-409, 869 in the Anuśāsanaparva of the Mahābhārata) are the cumulative essence of Śiva's total personality. Śankiara in the Dakșināmūri-stotra in ten stanzas (commented by Śr̄̄ Sureśvarācārya in Mānasollāsa) invokes (Vasanthakumari 2003: 12-13, 15): Tasmai Śrīgurumūrtaye nama yidạ̣ Śrī Dakṣināmūrttaye - "Extol the great Auspicious Teacher, He is Śrī Dakṣiṇāmūrti". The Vaișnavas claim the same status for Viṣnu as Guruh and Gurutamah (Viṣnusahasranāma 209-210).
} 
Mūvarāya mutaloruvañ... (Tēvāram 1.53.1)

“The three are He-on-flower (Brahmā), the red-eyed-Māl (Viṣṇu) and Íśvara; One, He is three ..."

That is to say Śiva is perceived as Paśupati in the Vañcaikkalam tradition (vide, Attachment v. 7). He is the Mahādeva "Lord Great", an epithet that is shared by Śrī Rāma (cf. 'Mahādevāya namạ̣' in Rāmoṣtottaram-58).

\section{Rāmāyana Sculptures}

What is significant in the architectural setting is that Rammayana sculptures are inlaid on the ceiling of the eastern porch at the level of prastara. These are bracket motifs as though supporting the roof with the prastara appearing on the four-pillars. The events illustrated are mostly from the Bālakand episodes from the first kānda and not the other seven is obscure ${ }^{21}$; may be arbitrary and random. Early narrative sculptures on the Rāmāyaṇa (e.g. Kailāsa of Ellora, Upper Śivālaya of Badāmī, Durgā temple of Aihole and so on) do not present a continuous array of episodes from the Bāla- to the Uttara- kāndas (cf. Gail 1985: 177-86, Rajarajan 2001: 783-97, Kalidos 2006: II, chaps. II \& III). The events are also not continuous as it may be found in Vālmīki or any vernacular version, and jump from one event to the other without any link. This strange phenomenon could not be explained (cf. Dehejia 1998: 80-106). We find both these paradoxes meeting in the portrayal of Vañcaikkalam-Rāmāyana ${ }^{22}$. For the sake of continuity in narration the sculptures are rearranged as follows:

1. Rāma and Daśaratha, 2. Rāma and Lakṣmaṇa, 3. Rāma as dhanurdhara, 4. Daśaratha, Sumantra and Viśvāmitra, 5. Viśvāmitra

\footnotetext{
${ }^{21}$ The other kāṇ das are named Ayodhyā-, Arranya-, Kiṣkinda-, Sundara-, Yuddha- and Uttara-. Vernacular versions of the epic have selected few of these kändas for rendering in Tamil, Malaiyālam, Telugu, and Kaṇnạ̣a. For example, Kampar in his Tamil Irāmāvatāram omits the Uttarakānda. Kōna Buddharāja's (fourteenth century) sons wrote the Uttara-Rāmāyana in Telugu. The anonymous Rāmacaritram (c. tenththirteenth centuries) in Malaiyālam deals with the Yuddhakānda (Sastri 1971: 418).

${ }^{22}$ Bhațkal in coastal Karnāṭaka on the upper fringes of Kēraḷa illustrates incomplete Rāmāyaṇa reliefs (Dallapiccola et al. 2005: 253-308, Jeyapriya 2010: 112-16, Kalidos 2014: 113-38).
} 
teaching archery to Rāma, 6. Viśvāmitra, Rāma and Lakșmaṇa, 7. Tātakā-vadham, 8. Viśvāmitra's yajña, 9. Redemption of Ahalyā.

Vālmīki's narration of the epic would add Daśaratha begot four sons through his queens after a putrakāmești-yajña. Rāma grew up to manhood trained in archery by his kulaguru, Vasiștha. Sage Viśvāmitra approached Daśaratha to take Rāma to the forest in order to do away with the menace of rākșasas. The reluctant Daśaratha consoles himself, and permits Rāma to accompany the brahmarșiViśvāmitra to the forest. Lakṣmaṇa follows his brother. Rāma kills the demons in forest, including the ogress, Tāṭakā. Viśvāmitra completes his yajña for peace of the world. He conducts Rāma and Lakșmaṇa to Mithilā. On the way Rāma sets his foot on a stone that was cursed Ahalyā, wife of sage Gautama. She is redeemed ${ }^{23}$. The wooden sculptures on the east-porch of the Mahādeva temple at Vañcaikkalam mostly pertain to these events. It may add these are unreported in any scholarly study.

1. Dāśarathi-Rāma and Daśaratha appear together that may show the love of the mahārāja for his son (Fig. 8). Rāma is not armed, which means both the father and his beloved son discuss the question relating to the need of sage Viśvāmitra. He had arrived at the palace in Ayodhyā (contextually Vañcaikkalam temple ${ }^{24}$ ) seeking the help of Daśaratha. Both the king and prince are crowned and wear apparels in the Mughal fashion that is a clue the date the sculptures in the eighteenth century (cf. Jeyapriya 2009a: pl. VIII ${ }^{25}$ ). They are sthānaka (standing mode). The rich ornaments on both the persons display Kērala exuberance imbibed partly with Kathakali influence. It is a set pattern in all illustrations under study. The right hands of both the personalities are in

\footnotetext{
${ }^{23}$ All these events take place in sargah (canto) 18 to 51 of Vālmīki-Rāmāyana.

${ }^{24}$ Considering a south Indian sthala-kșetra the venue of Rāmayyana event is not unpopular. For example, the Mātanga-parvata in Vijayanagara/Hampi is treated the Kișkinda of the Rámāyana (Settar n.d.: 24). The Viṣnu temple of Citamparam, the Cillai-Cittirakūtam is considered the Citrakūta of Rāmāyaṇa in Kulaśekhara Ālvār's hymns (see note 3, Kalidos 1997: 22). Kulaśekhara was a genius who compresses the mahā-Rāmāyaṇa, including the Uttarakāṇ̣a in eleven hymns (Perumāl Tirumoli 10.1-11).

${ }^{25}$ This is a wood-carved image from the temple car of the Rāma temple at Vatuvūr, Tañcāvūr district. See R.K.K. Rajarajan, 'Rāmāyaṇa Paintings of the Tirukōkaraṇam Temple' MS (Alexander von Humboldt post-doctoral report of the Free University Berlin, Berlin 2002 - Unquoted in References).
} 
vismayamudra, expressing wonder; perhaps at the warrant of Viśvāmitra and dismay of Daśaratha.

2. Rāma and Lakṣmaṇa are sthānaka (Fig. 9). Lakṣmaṇa appears behind Rāma. They perhaps discuss the prospects of war with demons in the forest that hinder the sacrifices of rșis. A frieze of couchant peacocks with folded plumages extending backwards appears at the bottom to add to the aesthetics of composition. The apparel and ornaments are rich.

3. Rāma in Indian tradition is celebrated for three uttama-gunas (cf. Rāmāṣtottaram epithet 37 'Triguṇātma'); viz.,

i) Puruṣa-lakșana, ii) Dhanurdhara (expert archer) to uphold dharma, and iii) Rāma-rājya, champion of the best administered best government; the dreamland/utopia of Mahātma Gāndhi ${ }^{26}$.

The present image shows Rāma majestically holding the dhanus, and so dhanurdhara (Fig. 10). It suggests he is equipped to go with Viśvāmitra to accomplish his manifest duty in the aranya "forest". The image is slightly tribhanga and royally decorated. The dhanus in the right hand is broken. The left is in katihasta.

4. Daśaratha, Viśvāmitra and Sumantra are present (Fig. 11). Viśvāmitra is annoyed at the refusal of Daśaratha to depart with Rāma. Sumantra perhaps persuades Daśaratha to yield to the request of Viśvāmitra. It is only afterwards that the heroism of Rāma is let known to the world. Rāma's association with Viśvāmitra not only led to the rendition of demons but also taking the hand of Șitā in Mithilā. The image shows Viśvāmitra holding a chhatrāvali, and moving away. Daśaratha follows him and is inclined to yield to the request of Viśvāmitra.

5. Viśvāmitra and Rāma are perhaps discussing how to do away with the demons that cause sacrilegious harm to the sacrifices. Viśvāmitra is seated in mahārājalīlāsana on an ornamental wooden pedestal. Rāma stands nearby meekly listening to the discourse of the sage (Fig. 12). He is perhaps teaching dhanurśāstra to Rāma. Vālmīki says the sage taught him how to obtain divine missiles, bāna and how to employ these in time

\footnotetext{
${ }^{26} \mathrm{Cf}$. the following epithets of the Rāmāștottara: Mahāpuruṣa-70 "Great Man", Purānapurușottama-73 "Primeval Best Man", Dhanurdhara-90 "Wielder of the Bow", Harakodaṇ̣akhaṇḍana-27 "Wielder of the bow of Hara/Śiva" (Śivadhanus broken in the svayamvara at Mithilā*), Rājīvalocana-5 "Face of (best) Administration" and so on.

* The confrontation between kṣatriya-Dāśarathi-Rāma and brāhmana-Paraśurāma led to the breaking of Viṣnudhanus (Bālakāṇda, Sargas 75-76).
} 
of need ${ }^{27}$. The Rāmāștottaram invokes the Lord with the epithet, Viśvāmitrapriya-13 “(Rāma) the beloved of Viśvāmitra”.

6. The illustration presents Viśvāmitra, Rāma and Lakṣmaṇa standing in a row (Fig. 13). Having learnt the intricacies of dhanurśāstra from the sage, Rāma entreats the same be taught to Lakșmana (Rāmāyaña, Bālakāṇ̣a, Sarga 28).

7. The next scene pertains to the slaughter of Tātakā by Rāma. Vālmīki says Rāma was reluctant to kill a woman. At that time Tātakā rushed toward Rāma lifting her arms and roaring. She threw a huge cloud of dust and rocks. Angry at these insinuating acts of Tātakā, Rāma cut off her arms. Lakșmaṇa deprived her of her ears and tip of nose (Bālakāṇ̣̂, Sarga 26). She and her brothers were killed. The wood carving shows a gruesome creature of short and clumsy stature. The mouth is wide agape and canine teeth protruding (Fig. 14). She is covered with kaupina-like garment. The ornaments consist of thick circular iron fittings such as kañkaña, keyūra and anklets. The Rāmāstottara adds the epithet, Tāṭakānta-31 "Destroyer of Tāṭakā (the evil-monger)".

Of all the images examined so far, the figure of Tātakā is most striking from the iconographic point of view. Thematically, it purports to illustrate whatever may be thrust with which terrorism [dharmadroha] rock at a high pitch dharma wins the race in the long run. This is the basic message that Indian religion, philosophy and art teaches to the global community of peace-lovers [dharmātma].

The sculptors and poets of the Vañcaikkalam sthala (vide, Attachment) do tell us the manifest purpose behind the avatäras and manifestations of Devī-Bhagavatī, Viṣnu and Śiva are annihilation of evil and installation of dharma.

8. The most striking illustration in the Ramanyana series is the yajña of Viśvāmitra. We do not know in which part of proto-historic India and at what point of time the sage conducted the yajña for global peace (infra). We find him readily present in the Vañcaikkalam temple in a corner performing the much-praised sacrifice, sanctified in literature since the

${ }^{27}$ Certain miraculous missiles are supposed to be not invited under ordinary circumstances. Such missiles, e.g. Brahmāstra should not be solicited and once obtained they could not be kept in abeyance, and must be released; e.g. Karna and Aśvatthāma and in both the cases Krṣna had to intercede and save the victims, Arjuna and Parikșit from impending catastrophe (Mani 1996: 159, cf. Dowson 1998: 29). In the Rämāyana (Bālakānda, Sarga 76, vv. 15-20) the problem arises when Rāma mounts a missile on the Viṣnu-dhanus when challenged by Paraśurāma. It was released to curtail the pride of the brāhmana-rsi. 
Rgvedic time. The sage is seated facing a fire-altar from which the combustion rises up. The sage is found pouring ingredients to cultivate the fire. Fire and illumination dispel darkness and evil, and usher in a paradise regained (Fig. 15).

9. Another illustration pertains to the redemption offered to Ahalyā, wife of sage Gautama forged and raped by Indra. The image shows Rāma standing majestically decorated in royal garments and ornaments. Ahalyā is already recovered from the cursed stone, and stands lifting the hands lifted up in namaskāramudra (Fig. 16). She is shown with full breasts not tugged with any upper cloth. The Rāmasstottaram adds the epithet, Ahalyāśāpavimokcana-44, the Lord that confers grace to Ahalyā. Rāma was the friend of the unfriended poor. He went to the help of the needy and the destitute but stands on crossroads in contemporary politics.

There may be several hundreds of sculptures and paintings on the Rāmāyana in South and Southeast Asia (e.g. Prāmbanan in Central $\mathrm{J} a \overline{v a})^{28}$ but those in the Vañcaikkalam temple constitute a genre. They exhibit visible traits of the culture of Kerrala in as far as the coiffeur and ornamental details are concerned, and thematically Vālmīki. Keral a is the homeland of the art in wood that is richly available in the hilly abode of the gods and goddesses. In fact, originally the temples of Kêrala were set against the background of the woods and water. However, a systematic survey of the temples in Keraḷa is needed in spite of the pioneering efforts of Sarkar 1978. Jayashanker 1997 is an excellent work in respect of "rituals" but lacks in temple architecture and iconography. The history of art in Kèrala stands behind the veil and efforts are taken to bring the hidden treasures to the limelight.

By way of conclusion the selection of the Rámāyana sculptures in a Siva temple may be explained. To begin with the Adhyātma Rāmāyanam by Tuñcat Rāmānujan Eluttaccan is an explication of the philosophy of the epic and glories of Rāma related by Śiva to Pārvati ${ }^{29}$. At the pan-Indian level, the Rāmāyana sculptures appear in temples of all sectarian lineages (e.g. the Chenna-Keśava and

\footnotetext{
${ }^{28}$ The author had an occasion to visit the island (July 2012, International Conference of the Association of Historians of Asia) and collected photographic materials that are pending publication.

${ }_{29}^{29}$ The poetic works in Malaiyālam are Rāmakathāp-pātțu by Ayyipiḷai Āśān, Rāmāyaña-campu by Punam Nambūdiri and Kaṇnaśśa-Rāmāyaṇam by Rāma Panikkar (fifteenth century).
} 
Hoysaleśvara at Bēlūr and Halebị̣̄u, cf. Settar 1992: II, pls. 188-189, 261). Therefore, it is no wonder if such heritages are imprinted in the Mahādeva of Vañcaikkalam. Two pan-Indian cultural idioms find a harmonious confluence in the art of Vañcaikkaḷm. They are Paśupati equated with Rāma-rājya ${ }^{30}$ and the Rāmeśvaram tradition in which Rāma is said to have instituted the Íśvaram at Setu (vide, the seventh century Tēvāram $3.268,3.359 ; 4.61)^{31}$. Mythology says Vañcaikkalam was the prathistha of [Paraśu-] Rāma.

The choice of themes from the Bālakānda of the Rāmāyana by the Kêralaputras (attested since the third century $\mathrm{BCE}^{32}$, cf. Aśoka's Girṇār Rock Edict in Mookerji 1972: 223) is unique because the $k \bar{a} a \underline{d} d a$ is full of joy and play, humour and seriousness at work ${ }^{33}$, and the great sages Viśvāmitra and Vasiștha bringing up the children of Raghu-kula to the full magnitude of martial splendor to safeguard dharma "righteousness" patritrāṇāya sādhūnām, and destroy evil vināśàya ca dușkrtām (Bhagavat Gìta 4.8). By the way it proclaims the message of India to world thought by emphasizing the purpose of yajña (sacrifice) and result of siddha (accomplishment) directed toward cosmic peace:

Oṃ Śāntiḥ Śāntiḥ Sāntiḥ, the invocatory verse in Upaniṣads

(Gambhīrānanda 1995: I 2, 34, 98)

\footnotetext{
${ }^{30}$ A popular Rāma-kìrti (or bhajan) song avowedly declars Rāma is Paśupati: "Daśaratha nandana Rāma Ram/Daśamukkha mardana Rāma Raṃa... Paśupati... Rāma Rām".

31 Cilaiyaṇnal ceytavi rāmēccuram "Rāmeśvaram established by Masterdhanurdhara" (Tèvāram 3.268.2).

32 Early authorities date the epic "before 500 B.C." (MacDonell 1979: 200). Modern research and theatrical formulae are subject to controversy (cf. Brockington 1998: chap. 7). These scholars strive to bring down the two mega-epics down to $500 \mathrm{CE}$ due to interpolation of later ideas, syntax and style. Even in such a case the epics may have to be dated during the pre-500 BCE to a convenient later date. Cf. Wendy Doniger (1994: 18) assigns the Skanda Purāna to 700-1150 CE. Doniger's date for the Rāmayana is $200 \mathrm{BCE}$ to $200 \mathrm{CE}$. In her scheme the Rāmāyana is post-Buddha, which could not be historical. Again, Doniger and "her children" (Tailor 2011: 149$68)$ are controversial authors. Two of Doniger's $(2009,2013)$ books have been proscribed in India.

${ }^{33}$ See the modern paintings in the 'Rāmacaritamanas Temple' at Vāran̄āsī where the children of 'Raghuvamiśa' are found happily playing tops (Kalidos 2010: 9-12, figs. BW 30-31).
} 
This meritorious act is projected in the wood carvings of the KēraliaMahādeva temple (Fig. 15), which again emphasizes the gunāmśa of Paśupati-Śiva. Paśupati is a cherished theme in the hymns of the Nāyañmār that Cēramān Perumāl celebrates. Pantanainallūr (Tēvāram 3.379, all hymns) in the Cōlanādu was a sthala, the hymns on which commemorate the celebrity of Paśupati. The same credit is shared by the hymns on Potu "Common-[Tillai/Citamparam]" (Tềvāram 4.111, all hymns). Paśupati is the Lord that eradicates karma, inheritances of the past; Pacupati-pāvanācan ${ }^{34}$ (ibid. 4.51.10). The Lord is above all the Eternal, Pacupati-paramētți (ibid. 7.92.1). He is the creator, and sustains the worlds (Noble 1981: 2). To our knowledge no temple in South India accommodates a chapel for Paśupati. This architectural setting and philosophical input is important to understand the cultural value of Vañcaikkaḷm.

Justifying the value of yajñas, Vālmīki in the Rāmāyaṇa says "The name of Siddhāśrama has been justified by being able to perform the yajña (without molestation from terrorists such as the asuras)". The purpose of yajña is cosmic peace and prosperity. Siva-Paśupati is Vedamaya and Yajñapriya $^{35}$. Vālmīki unequivocally adds ${ }^{36}$ :

$$
\begin{aligned}
& \text { Atha yajñe samāpte tu Viśvāmitre Mahāmuniḥ/ } \\
& \text { Nirītikā diśo druṣdvā Kākusthamidamabravīt// } \\
& \text { Krrtārtho’smi mahābāho krọtạ̣ guruvacastvayā/ } \\
& \text { Siddhāśramidaṃ satyaṃ krọ̣ vīra mahāyaśạ̣/ } \\
& \text { Sa hi Rāmaṃpraśasyaivaṃ tābhyāṃsandyāmupāgamat// }
\end{aligned}
$$

Vālmīki-Rāmāyaṇa, Bālakāṇ̣a, Sarga 30, vv. 25-30)

\footnotetext{
34 'Nārāyaṇa' (Viṣnusahasranāma-245) gets closer to the concept of Paśupati who pervades through the naras (nara + ayana); cf. Nara-Nārāyaṇa (Williams 1983: fig. 206). Viṣnu is Viśodhanạ (ibid. 637) that "destroys sins".

35 Cf. the Śivasaharanāma epithets: Vedakārāya-426, Yajñāya-275/529, Siddhbhūtārtha-99, Siddhārthacchandovyākaranottara-677 (accomplished end of the Veda and vyākarana).

${ }^{36}$ Kampa-Irāmāyaṇam (Pālakāṇtam, 8.38) adds: Vētanūl muraimaiyāl vēlvi murruvōrkku, İtu avātu illai... - "No evil haunts one that performs the Vedic sacrifice as told in the Vedas". The same advice was given to Kēralaputra-Cenikutțuvan, supposed to be the uterine brother of Illankē, author of Cilappatikāram (28.176-78) Perunal vēlvi nī ceyal vēṇtūm - "You must perform the good great sacrifice". It is a pointer of the fact that Kērala was the sacred venue of sacred sacrifices from time immemorial.
} 
An optimistic scholar steeped in pan-Indian heritage may add Vañcaikkaḷam is the Siddhāśrama where the great sage, Paraśurāma set his footprints in the creation mythology of Kēraḷ, and again he was the legendary founder of Mēltali i-Vañcaikkalam.

\section{Attachment}

Transcription and Summary of Hymns bearing on Vañcaikkalam (Tèvāram 7.4, Cuppiramaṇiyan 2007: 510-11)

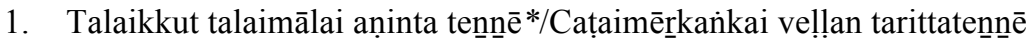
Alaikkum pilittōlkoṇ țacaitta tennnēe/Atan̄mēr katanākam kaccārtta tennn̄ē Malaikku nikarop pañavan tiraikal /Valitter r rimulañ kivalam purikoṇ Ṭalaikkun kaṭalan̉ karaimēl makōtai/Aṇiyār polilañ caikkaḷat tappan̄ē

* It is exclamatory alliteration and suggests "What a wonder?" "How marvelous a tour de force?" "How wonderfully done?" and so on.

"How nice it is to deck the head with a tiara! How nice it is to hold the waters of Gangā on the ochre-hued matted locks! How nice it is to put on the tiger's hide! How nice it is to fit in the black snake! The abode of Lord of Vañcaikkalam is amid a landscape of pools where the waves of the sea rise up above the hills circumambulating the venue".

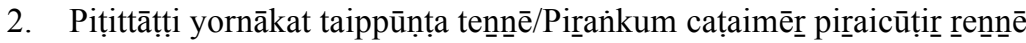
Poṭit tāñkoṇ țumeymur rumpūcir rennn̄ē/Pukarēru kantēral purinta tennn̄ē Maṭit tōț̣an tuvañtirai yerriyița/Vaḷarcañkam an̉kāttu muttañ coriya Aṭittār kaṭalan̉ karaimēl makōtai/Aṇiyār polilañ caikkaḷat tappan̄ē

"Caught, tossed and ornamented a snake (on Thy mien [cf. Kalidos 2012: 43-48, fig. 4])! How nice to put on the crescent on hanging locks! How nice to smear the dust [bhasma] all over the body (cf. Têvāram 1.202, Kalidos 2006: II 68-70)! How nice it is to mount the celebrated Bull! The abode of the Lord of Vañcaikkalam on the seashore is full of pools where waves of the sea dash on the shore and pearls pour from mature conchs". 
3. Cintit teluvārkku nellik kan̄iyē/Ciriyyār periyār manattuēra lựrāl Muntit tolıvā rịavār piravār/Muñika! muñiyē amarark kamarā Cantit tațamāl varaipōl tiraikaḷ/Taṇiyātu ițaruñ kațalan karaimēl Antit talaiccekkar vānēe yottiyā/Vañiyār poliliañ caikkaḷat tappan̄ē

"Thou are the nelli* (Phyllanthus emblica) fruit for those meditate on Thee! Thou ascend into the minds of the big and the small beings! They do not die and are not reborn! Sage among sages! God among gods! Thou Lord of Vañcaikkalam! Thou resemble the black-hill where the red-hot sun descends and that is dashed by waves of the sea".

* Believed to endow immortality (Subrahmanian 1990: 512).

4. Ilaikkum eluttuk kuyirē yottiyāl/Ilaiyē yottiyā lunaiyē yottiyāạ

Kulaikkum payirkkōr puyalē ottiyāl/Ațiyār tamakkōr kuțiyē yottiyāl

Malaikku nikarop pannavan tiraikalı//Valitter r rimulañ kivalam purikoṇ

Ṭalaikkuñ kațalan̉ karaimēl makōtai/Aṇiyār poliliañ caikkaḷat tappanēē

"Thou are the soul of letters. Though are the rims of the wheel, which if extolled offers grace even to the grass. The waves of the sea rise up as a hill and dash on the shore where the Lord Añcaikkalattapan finds his resort".

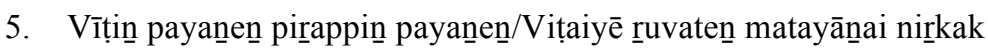

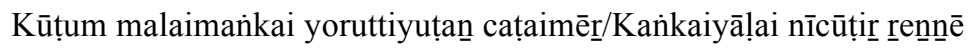

Pāṭum pulavark karuḷum poruḷn/Nitiyam palace takalac celavil

Āṭun kațalañ karaimēl makōtai/Aṇiyār polilañ caikkaḷat tappan̄ē

"What use is a house? What use is with a birth? How nice (the Lord) to unite with the hill-maid, and mount the she-Gangā on matted-locks! The rhyming poets are richly rewarded. Añcaikkalattappan is present amid a venue of pools where the sea dances on shore".

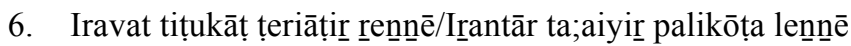

Paravit tolluvār pera paṇța mennēē/Parmā paramētți paṇintaruḷāy

Uravan toțucan̉ka mōṭippi muttam/Koṇarnterri mulan̉ki valampuri koṇṭu 
Aravak kațalan̉ karaimēl makōtai/Aṇiyār polilañ caikaḷat tappan̄ē

"What an awful bliss is to dance in crematorium during midnight! How wonderful to seek alms in skulls of the dead! What gratification do the intense prayers derive? Thou the Eternal Being do assure eternity! The Lord of Vañcaikkalam is on the shore of the sea that is scattered with conchs, pearls and the right-warped shells."

7. Ākkum alivum amaivum nī eṇpavan nāñ/Colluvār corporu lavai nī eñpan nān

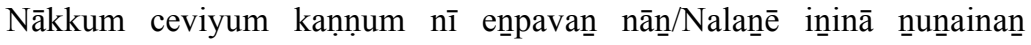
kuṇarntēn

Nōkkum nitiyam palavet tan̄aiyuñ/Kalattị pukappeytu koṇțura nunti

Ārkkum kațalan̉ karaimēl makōtai aṇiyār polilañ caikkaḷat tappan̄ē

"I say Thou are creation, destruction and the established order! I say You are the meaning of the words uttered! I say Thou are the tongue (that speaks), the ears (that hear) and the eyes (that see)! I have experienced Thou amply! Thou are the Lord of Añcaikkalam full of pools where on the shore of the sea riches are accumulated".

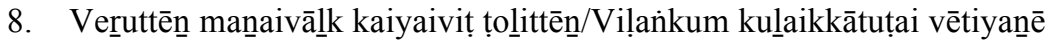
Iruttāy Ilañkaik kiraiyā yavañait/Talaipattoṭu tōḷala irrru vilak

Karuttāy kațalnañ cumutuṇṭu kaṇțam/Kațukap Piramañ talaiain tilupon

Rarittāy kațalan̉ karaimēl makōtai/Aṇiyār polilañ caikkaḷat tappan̄ē

"I have discarded family-life and am detached. Thou! The Vedaincarnate wears the shining ear-pendant. Thou took to task the King of Lankā and severed his ten-heads and strong shoulders. Thou chopped off one of the five-heads of Brahmā. Thou are Lord of Vañcaikkalam of waves dashing against the shore that is full of pools".

9. Piṭikkun̉ kaḷirēe yottiyā yempirān̄/Piramarkum pirān̄marrai māākumpirān̄

Noṭikkum alavir puramūn̄reriyac cilaitoț/Tavan̄ē unainān̄ maravēñ

Vațikkin ranapapō cilavan tiraikaḷ/Valitterri mulaniki valam purikoṇ

Ṭaṭikkun kaṭalan̉ karaimēl makōtai/Aṇiyār polilañ caikkaḷat tappan̄ē 
"My Lord is the bull-elephant, kali iru that mates the cow-elephant, piti (cf. Tèvāram 4.3.1). He is the Lord of Brahmā, and the Lord of Māl/Viṣnu. By the stroke of a moment, he mounted the bow to topple the triple-forts, tripuras. I will not forget you. Thou are the Lord of Vañcaikkalam on the shore washed by the oceanic waters and are full of enchanting ponds"”.

* Cuntarar says Vañcaikkalam was located on the sea-shore. The notation relating to "pools" or "ponds" maybe the backwaters in addition to the waterstores close to the temple meant for temple rituals (Fig. 6). Such a tank is also found close to the Kaṇnaki-Bhadrakālī temple of Koṭunkallūr.

10. Entam aṭikalimaiyōr perumā nַeñakkeñ/R̂malik kummaṇi mițarran

Antaṇ kațalan karaimēl makōtai/Aṇiyār polilañ caikkaḷat tappanai

Mantam mulavuñ kulalum iyampum/Vaḷarnāva larkōñ Nampiyū ranconnna

Cantam mikutan Tamilmālai kaḷoṇ/Ṭațivīla vallār tațumār r rilarē

"The Lord is the Mater of His servants, whose throat is smeared with the poison of the ocean. He is the Master of Vañcaikkalam. The venue resounds with the music of drums, flutes and other instruments (mattam, mulavam and kulal cf. Kalidos 2006: II, 73). If one sings the hymns of Nampiyūran of Nāvalūr, he is blessed." 


\section{Figures}

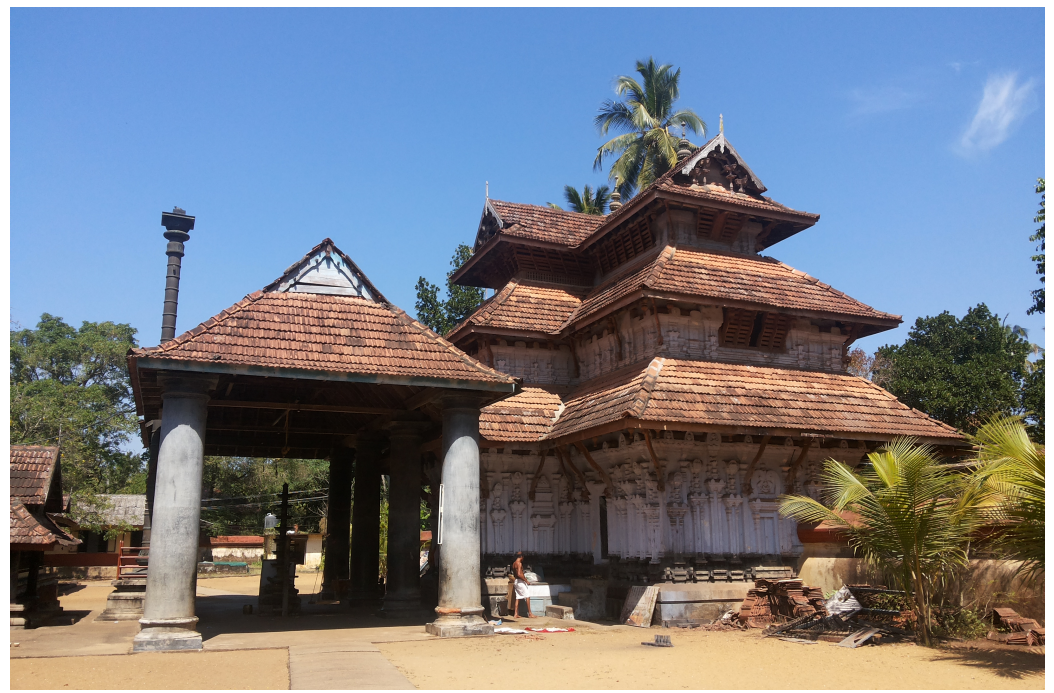

Figure 2: East gopuras

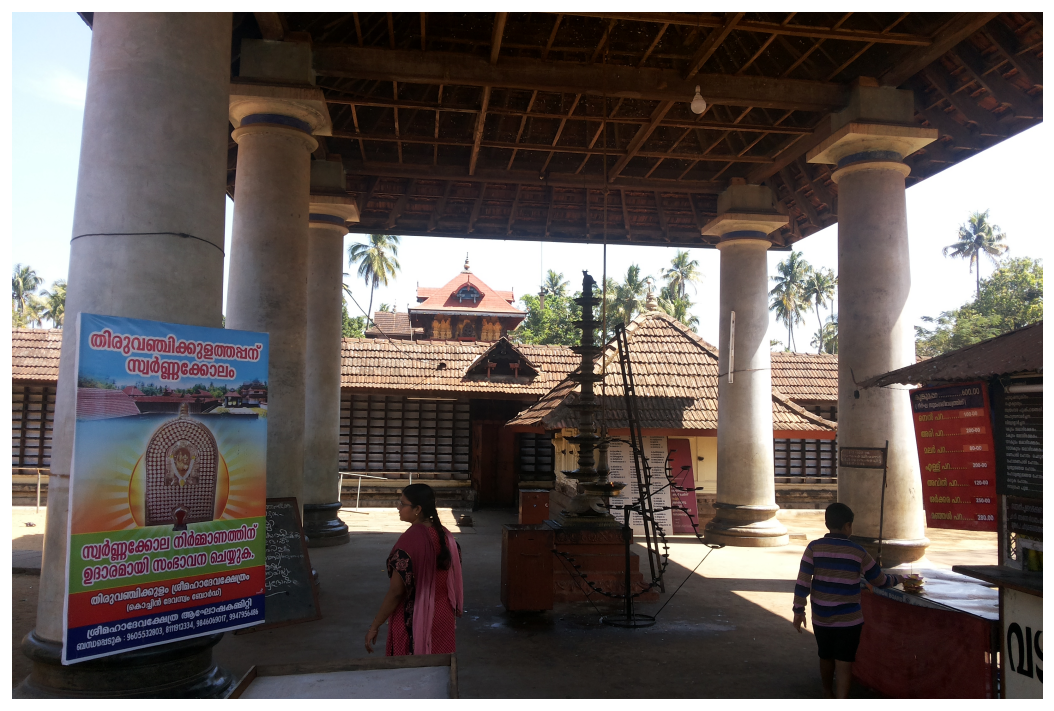

Figure 3: West $d v \bar{a} r a s ́ o b h \bar{a}$ 


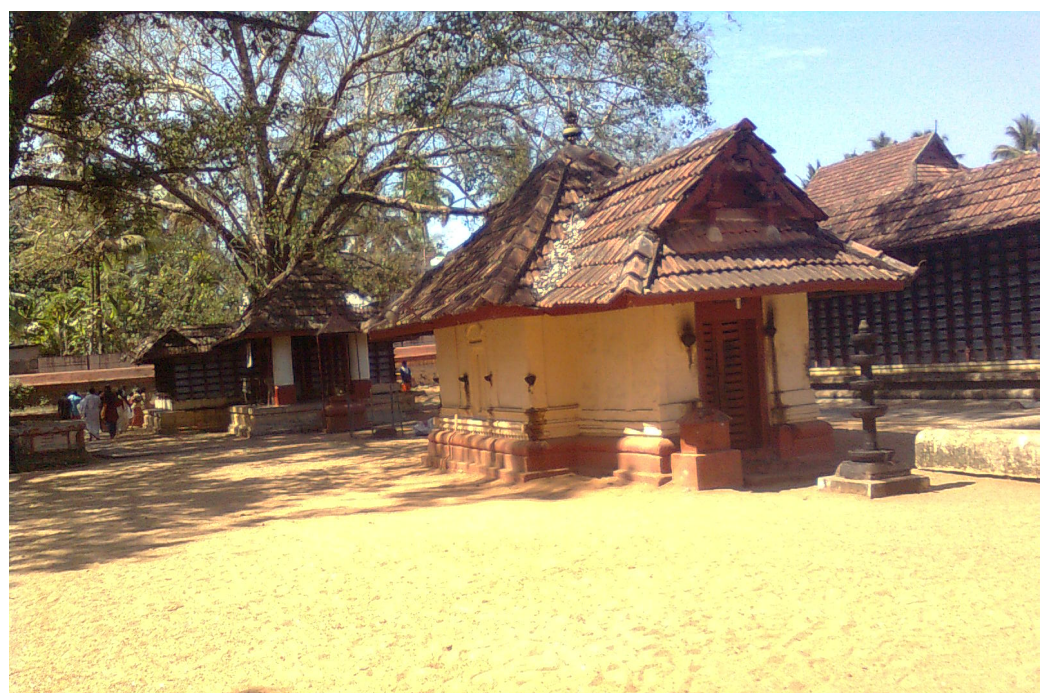

Figure 4: Dakṣināmūrti shrine

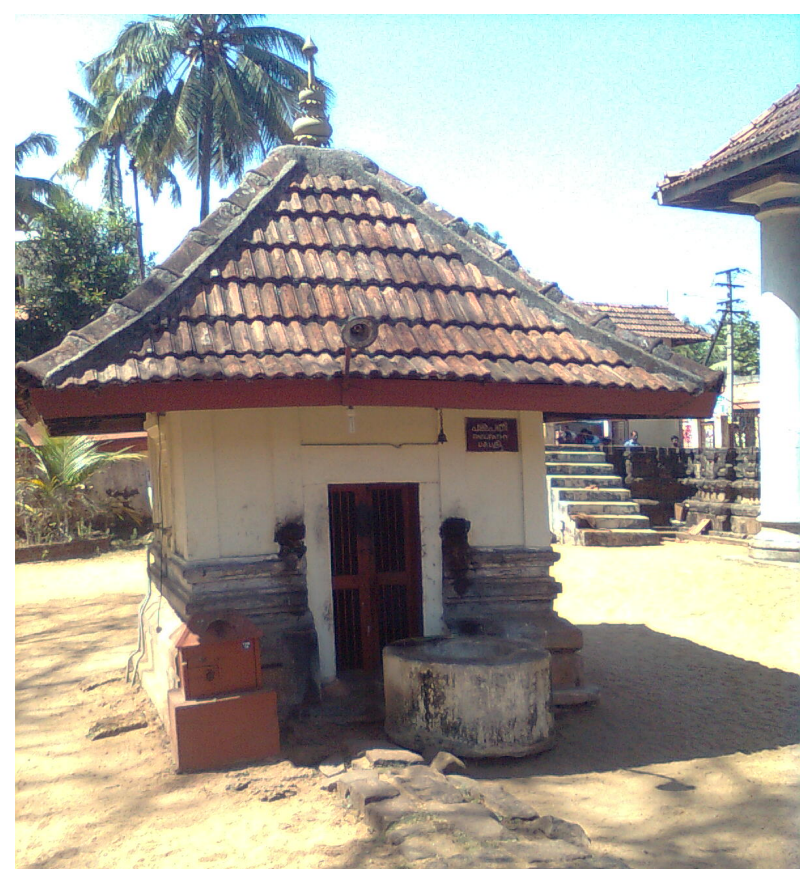

Figure 5: Paśupati shrine 


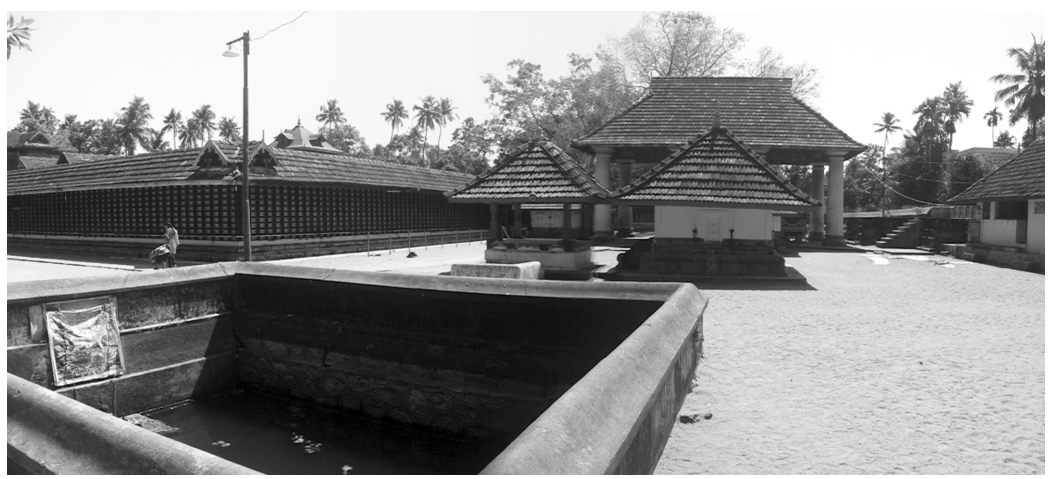

Figure 6: Temple tank and shrines nearby

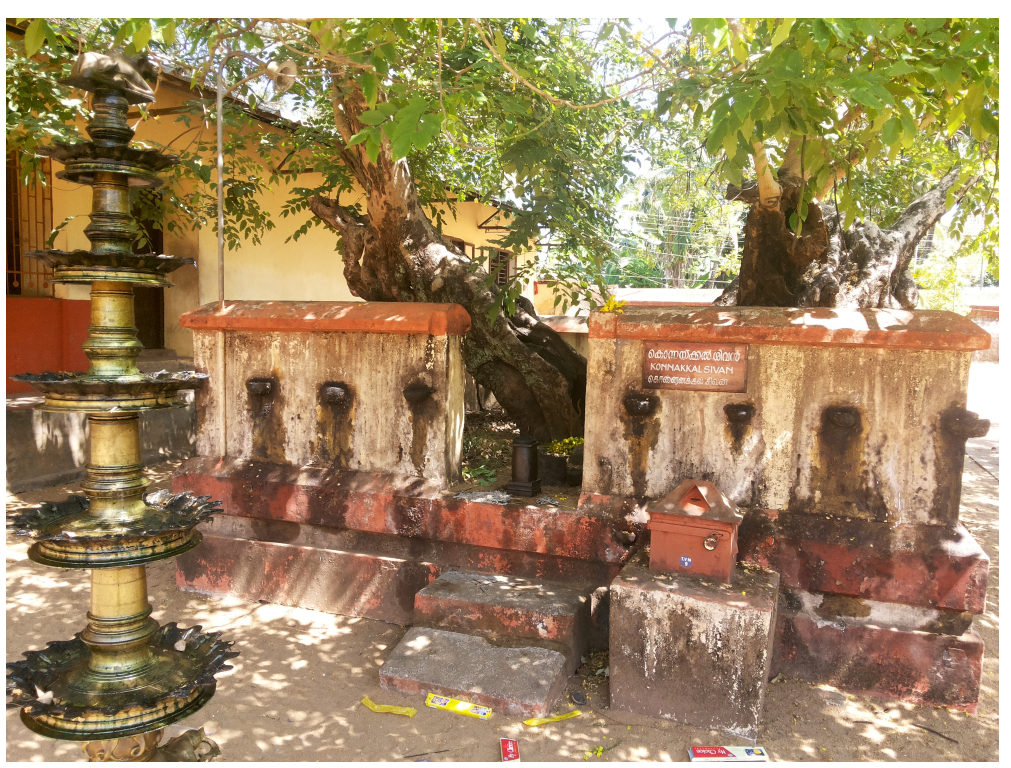

Figure 7: Konnai trees and Linga 


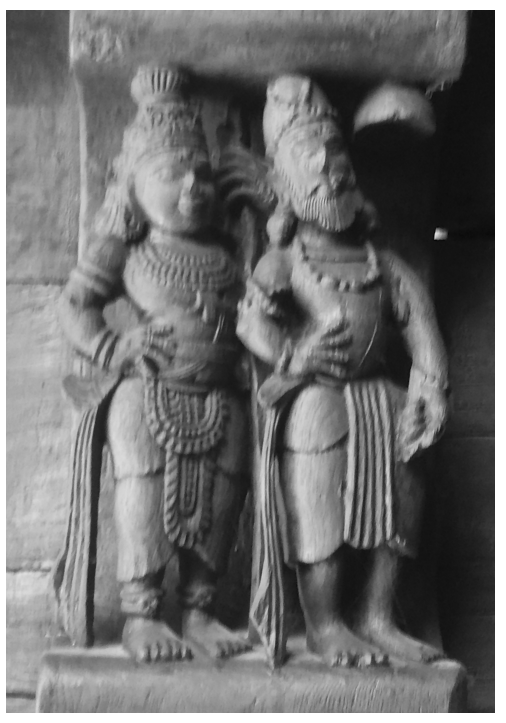

Figure 8 Daśaratha and Rāma

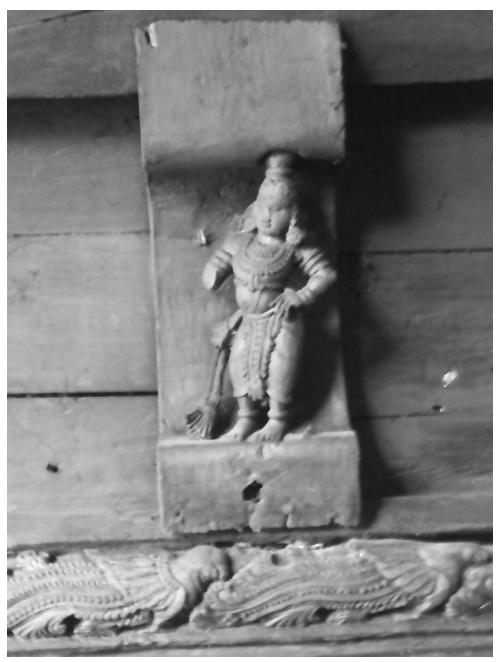

Figure 10: Dharnurdhara-Rāma

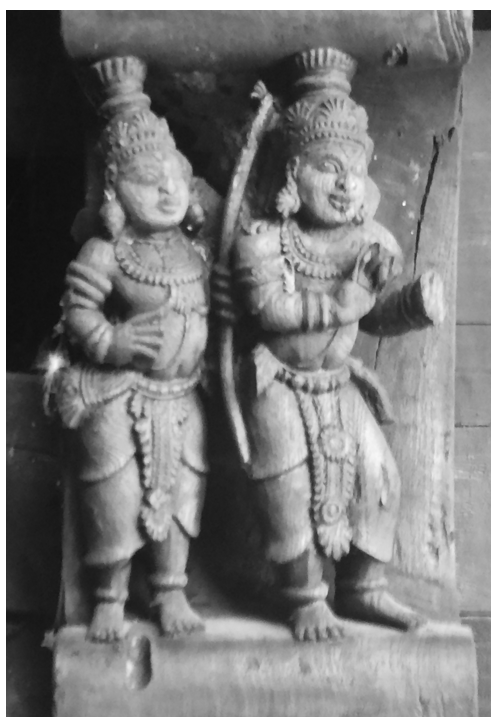

Figure 9: Rāma and Lakṣmaṇa

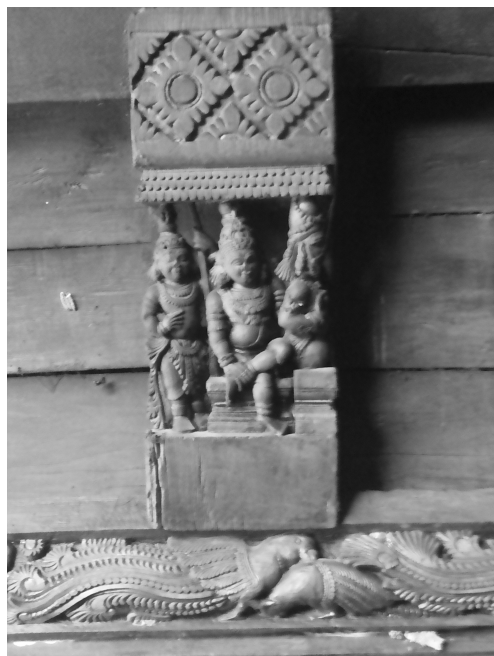

Figure 11: Daśaratha, Viśvāmitra and Sumantra 


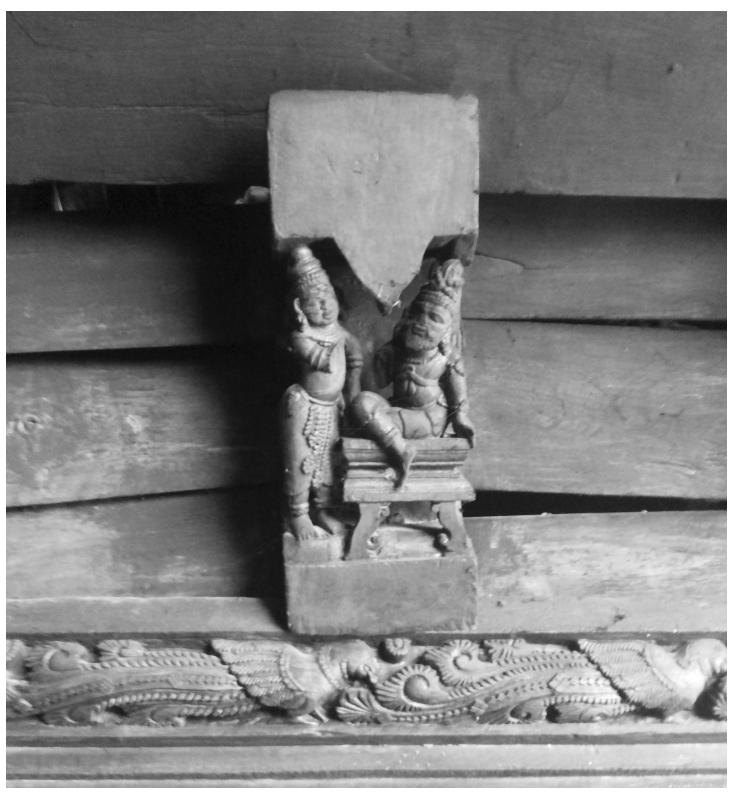

Figure 12: Viśvāmitra and Rāma

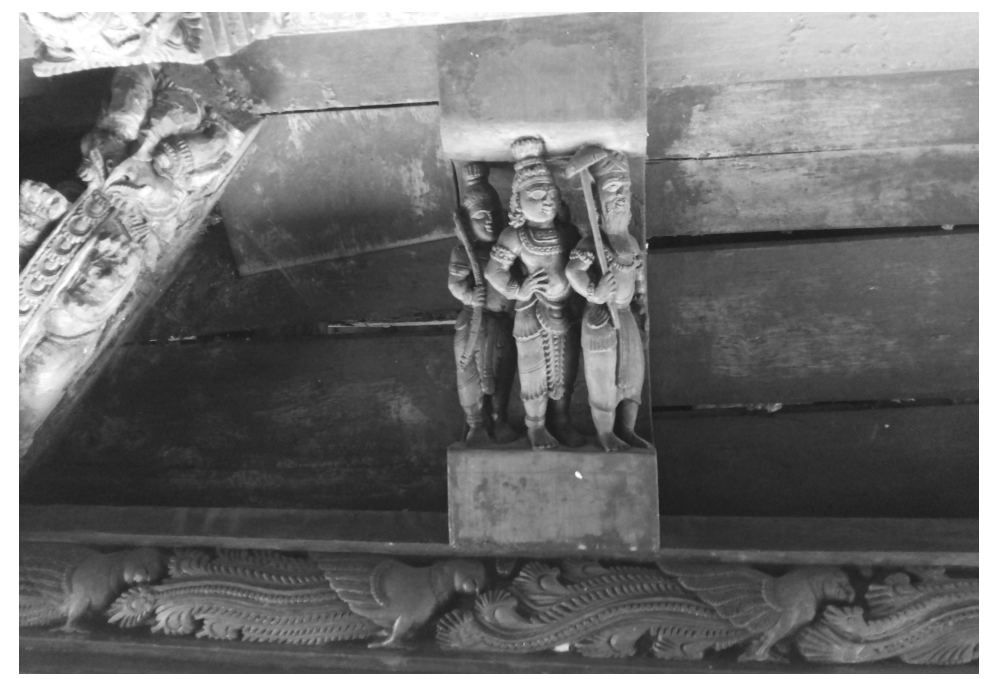

Figure 13: Viśvāmitra, Rāma and Lakṣmaṇa 


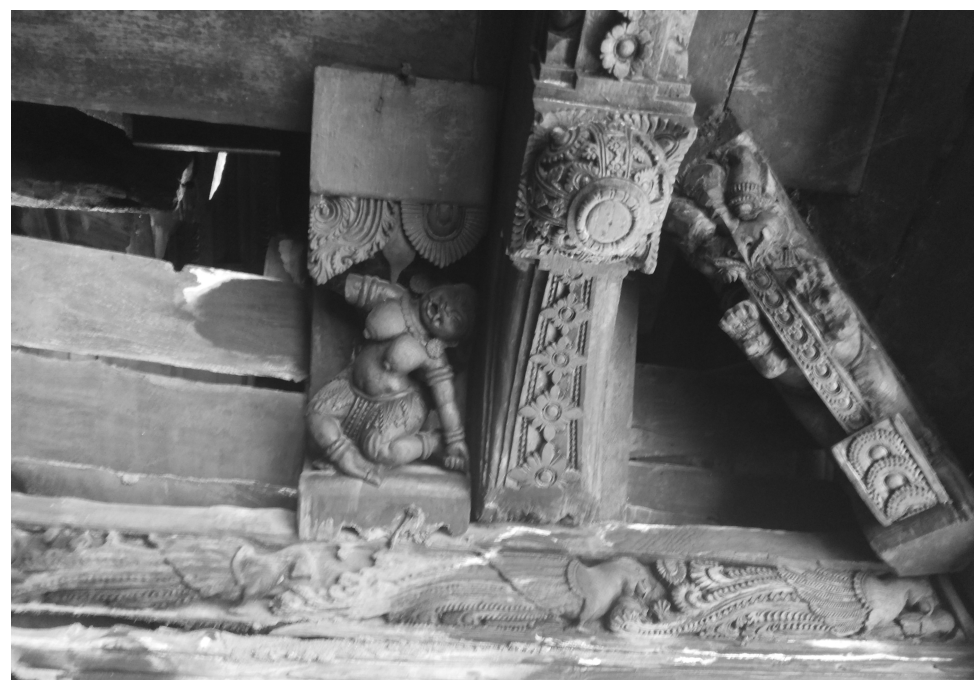

Figure 14: Tāṭakā-vadham

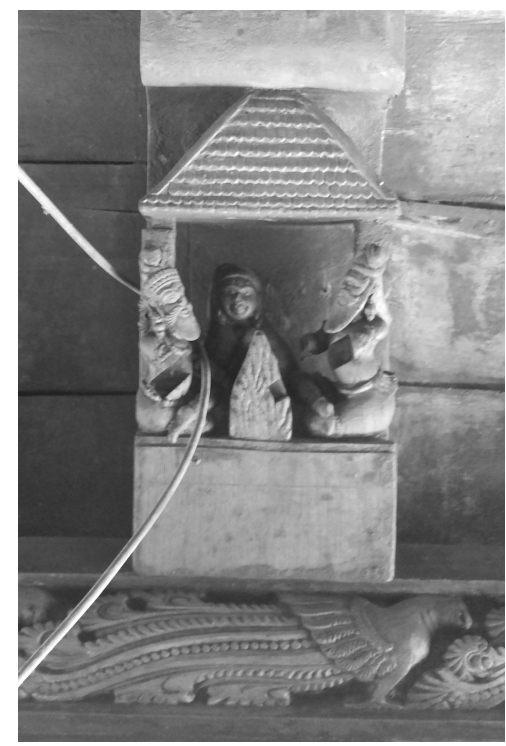

Figure 15: Viśvāmitra's yajña

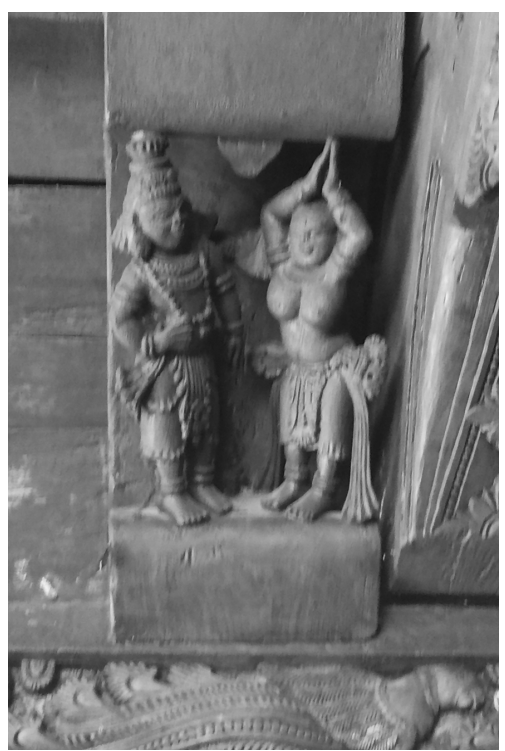

Figure 16: Ahalyā Redeemed 


\section{References}

Adhyātma-Rāmāuanam in Tamil n.d. Gita Press: Gorakhpur.

Auboyer, Jeanmine 1969/1994. Srī Ranganāthaswāmi. A Temple of Vishnu in Srirangam (Madras, India). Women's Welfare Organization: Vedaranyam.

Basham, A.L. 1971. The Wonder that was India. Fontana Books \& Rupa: Calcutta.

Bhagavat Gìtā (in devanāgarī with Tamil transl.), ed. Svāmi Citbhavānanda, Śrī Rāmakrishṇa Maṭha: Tiruparāytturai/ Tiruchi.

Brockington, John 1998. Sanskrit Epics. Brill: Leiden.

Cilappatikāram, ed. Na.Mu. Vēnnkațacāmi Nātțāar, Rāmayya Patippakam: Chennai 2008/2011.

Cuppiramaṇiyañ, Ca.Vē. 2006. Pannnirutirumurai. Maṇivācakar Patippakam: Chennai.

Dallapiccola, Anna L. 1994. "A Mobile Rāmāyaṇa: Carvings on the Chariot of the Rāmasvāmi Temple, Kumbhakōnam”. South Asian Studies, 10: 11-24.

Dallapiccola, A.L. \& C. Branfoot 2005. "Temple Architecture in Bhatkal and the 'Rāmāyaṇa Tradition in Sixteenth-Century Coastal Karnataka”. Artibus Asiae, 65 (2): 253-308.

Dehejia, Vidya 1998. "India's Visual Narratives: the Dominance of Space over Time". In G.H.R. Tillotson ed. Paradigms of Indian Architecture. Space and Time in Representation and Design. Curzon: Richmond, Surrey.

Doniger, Wendy 1973/1994. Hindu Myths. Penguin: New Delhi.

2009. The Hindus. An Alternative History. Penguin: New York.

2013. On Hinduism. Penguin: New York.

Dowson, John 1998 (reprint). A Classical Dictionary of Hindu Mythology \& Religion. Rupa \& Co.: Calcutta. 
Gail, Adalbert J. 1985. "Rāmāyaṇa Relief am Kailāsa in Ellora". Berliner Indologische Studien, 1: 177-86.

Gentes, M.J. 1992. "Scandalizing the Goddess at Kodungallūr". Asian Folklore Studies, 51 (2): 295-322.

Gonda, Jan 1970. Śivaism and Viṣnuism: A Comparison. London.

Harle, J.C. 1963. Temple Gateways of South India. Oxford University Press: Oxford.

Jayashanker, S. 1997. Temples of Kerala. Directorate of Census Operations, Kerala: New Delhi.

Jeyapriya-Rajarajan 2001. "The Śrīranggam Temple: Its Early Phase". Proceedings of the South Indian History Congress, 612-615. Tiruchirappalli.

- 2009. Terrific Manifestations of Śiva: Vìrabhadra. Sharada Publishing House: Delhi.

_ 2009a. "Rare Images in the Iconographic Profile of Nāyaka Art". Annali dell' Universita di Napoli "L' Orientale”, 69: 15765 .

_ 2010. "Rāmāyaṇa Sculptures of the Bhațkal Temple". In R.K.K. Rajarajan ed. 2010: 113-16.

_ 2014. "Vènkaṭam in the Hymns of the Ālvārs". Dr P. Chenna Reddy Festschrift, 3 vols. Sharada Publishing House Delhi (forthcoming).

Kalidos, Raju 1988. "The Wood Carvings of Tamilnadu: An Iconographical Survey". Journal of the Royal Asiatic Society of Great Britain and Ireland (London), No. 1: 98-125 (figs. 10). 1989. Temple Cars of Medieval Tamilaham. Vijay Publications: Madurai.

1991. "Pañcamukha-Āñjaneya in Canonic Literature and Art". East and West, 41 (1-4): 133-51.

1993-1995. "Tiruvarañkam, the Temple City. Glimpses from the Nālāyiram”. Tamil Civilization, 11-13: 136-52. 
1996. "Pullamankai in its Historical Setting". Journal of the Institute of Asian Studies, XIII (2): 141-53.

1997. “Antiquity of Tillai-Cittirakūṭam”. South Asian Studies (Oxford \& IBH), 13: 17-24.

2006. Encyclopaedia of Hindu Iconography: Early Medieval, 4 vols.* Sharada Publishing House: Delhi. * I Viṣnu, II Śiva, III Śakti Goddesses, IV. i Gaṇapati \& Skanda-Murukan, IV. ii Brahmā and Other Deities.

2010. "Vāraṇāsī Changing Cultural Values". In R.K.K.

Rajarajan ed. 2010: 9-12.

_ 2012. "Tamil Literary Traditions: Their Relevance in the Study of Indian Arts". In Lorenzetti \& Scialpi eds. 2012: 33-75.

2014. "Bhațkal or Bhatkal: Some Thoughts for Consideration". In J. Soundararajan, Glimpses of VijayanagaraNāyaka Art. Sharada Publishing House: Delhi.

Kampa-Rāmāyaṇam/Irāmāvatāram, Kampam Kalakam ed. Chennai 1976.

Kannan, K. 2006. 'Vaiṣnava Temples of the Tiruvārūr Region' (Ph.D. diss. The Tamil University). Thanjavur.

Kaśyapaśilolpaśāstra, 2 vols. 1960 \& 1968. Sarasvatī Mahal Libray: Thanjavur.

Kramrisch, Stella \& Vadudeva Poduval 1970. The Arts and Crafts of Kerala. Paico Publishing House: Cochin.

Kumar, M.P. Ajit 2013. "Francis Xavier and the Goa Inquisition". The Quarterly Journal of the Mythic Society, 104 (4): 21-29.

Lorenzetti, Tiziana 1996. The Iconography of Śiva-Paśupati (Ph.D. diss. University of Genoa). Genoa.

Lorenzetti, T. \& Fabio Scialpi eds. 2012. Glimpses of Indian History and Art: Reflections on the Past, Perspectives for the Future. Sapienza University of Rome: Rome.

MacDonell, Arthur A. 1899/1979. A History of Sanskrit Literature. Motilal Banarsidass: Delhi. 
Mani, Vettam 1964/1996. Purānic Encyclopaedia. Motilal Banarsidass: Delhi.

Maxwell, T.S. (1983) "The Evidence for a Viśvarūpa Iconographic Tradition in Western India, $6^{\text {th }}-9^{\text {th }}$ Centuries A.D." Artibus Asiae, 44: 3, 213-34.

Mookerji, Radhakumud 1928/1972. Asoka. Motilal Bnarsidass: Delhi.

Mayamata. An Indian Treatise on Housing Architecture and Iconography. Transl. Bruno Dagens 1985. Sitaram Bhartia Institute of Scientific Technology: New Delhi.

'Nālāyiram': Nālāyirativviyappirapantam, Little Flower Company ed. Chennai: 1984/2008.

Noble, William A. 1981. "The Architecture and Organization of Kerala Style Hindu Temples". Anthropos, 76: 1-2, 1-24.

Patirruppattu, In Cuppiramaṇiyan ed. 2006: 400 (385-419).

Perumāl Tirumoli i, part of 'Nālāyiram'.

Pillai, V.R. Parameswaran 1986. Temple Culture of South India. InterIndia Publications: New Delhi.

PTA: Ponvvaṇnattiruvantāti, In Cuppiramaṇiyan ed. 2007: 956-61.

PTA: In Patin̄ōrāntirumurai, pp. 31-59. Kumarakuruparar Caṅkam ed., Śrīvaikuntam 1972.

Puruṣasūkta (devanāgari with Tamil transl.), Śrī Rāmakrishṇa Maṭha ed. Mayilāpūr/Chennai 1960/1974.

Rajarajan, R.K.K. 1998. "Iconographic Programme in Temple Cars. A Case Study of Kūṭal Alakar Tèr. East and West (Rome), 48 (34): 329-48.

2001. "Sītāpaharanam: Changing Thematic Idioms in Sanskrit and Tamil". In Dirk W. Lönne ed. Tofha-e-Dil Festschrift Helmut Nespital, 2 vols. Dr. Inge Wezler Verlag für Orientalistische Fachpublikationen: Reinbek.

2006. Art of the Vijayanagara-Nāyakas: Architecture \& Iconography, 2 vols. Sharada Publishing House: Delhi. 
2010 'Some Rare Sculptures of the 'Yester' Śrīvilliputtūr' Tēr”. In R.K.K. Rajarajan ed. 2010: 101-105.

ed. 2010. Studies in Art History of India. Sharada Publishing House: Delhi.

2012. Rock-cut Model Shrine in Early Indian Art. Sharada Publishing House: Delhi.

2013. Historical sequence of the Vaiṣnava Divyadeśas. Sacred venues of Vișṇism. Acta Orientalia, Vol. 74, pp. 37-90.

2013a. "Sacred Geography of Viṣnuism in the Kāviri Delta"*. Conference Paper MS, Gandhigram Rural University:

Gandhigram. * A comprehensive article in about 25,000 words that presents a kaleidoscopic picture of forty divyadeśas. It includes a passing reference to Vittuvakkōṭu with few photographic illustrations.

2014. "Vallavāl, the Sacred Abode of Viṣnu: Formation and Transformation"*. Ars Orientalis (communicated). * The article is illustrated with photographic samples and plans relating to Vallavā1/Tiruvalla, a divyadeśa in Kuț̣anāḍu.

2015. "Navagrahas in Indian Thought and Nāyaka Temples of Tamilnadu" In J. Soundararajan, Glimpses of VijayanagaraNãyaka Art, pp. 169-96. Sharada Publishing House: Delhi.

_ 2015a. Tears of Kannaki: Annals and Iconology of Cilappatikāram. Sharada Publishing House: Delhi (in press).

Rajarajan, R.K.K. \& Jeyapriya Rajarajan 2013. MīnākșīSundareśvara: 'Tiruvilaiyātạn Purānam in Letters, Design and Art. Sharada Publishing House: Delhi.

Ramakrishnan, S. 1993-95. "South Indian Temple Gopuras. Evolution of the Concept, Structure and Architecture". Tamil Civilization, 11-13, 83-94.

Rāmāṣtottaram, In Anādimañgalam K. Nārāyaṇasvāmi Ayyar ed. 'Sarvadevatāṣtottara-sadanāmāvalimālā', 43-48. Bhavani Book Center: Chennai.

Rāmāyaṇa of Vālmīki, 2 vols., Gita Press, Gorakhpur 1969/2001. 
Sarkar, H. 1973. Monuments of Kerala. Archaeological Survey of India: New Delhi.

1978. An Architectural Survey of Temples of Kerala. Archaeological Survey of India: New Delhi.

Sastri, K.A. Nilakanta 1971. A History of South India. Oxford University Press: London.

Sathyanathaier, R. 1964/1980. A Political and Cultural History of India, I. Visvanathan \& Co.: Madras.

Settar, S. n.d. Hampi A Medieval Metropolis. Kalayatra: Bangalore. 1992. The Hoysla Temples, 2 vols. Kalayatra: Bangalore.

Śivasahasranāma, Śr̄̄ Rāmakrishṇa Maṭha, Chennai 2002.

Spencer, G.W. 1970. "The Sacred Geography of the Tamil Shaivite Hymns". Numen, 17 (3): 232-44.

Sriraman, T.S. 2011. Cōla Murals: Documentation and Study of Cōla Murals of the Brhadīsvara Temple, Tañcāvūr. Archaeological Survey of India: New Delhi.

Śrittattvanidhi I (original grantha with Tamil transl.), ed. S.C. Subrahmanya Sastri, Tañcāvūr Sarasvatī Mahal Library, Tañcāvūr: 2007.

Subrahmanian, N. 1990. Pre-Pallavan Tamil Index. University of Madras: Madras.

TAS: Travancore Archaeological Series, Vol. I, Pt. I (8 vols).

Internet: temple.dinamalar.com

Tēvāram, 2 vols; ed. Po.Vē. Cōmacuntaranāàr 1973. Kalakam: Chennai: 1973.

Tèvāram, In Cuppiramaṇiyañ ed. 2007: 33-579.

Thurston, Edgar 1909. Castes and Tribes of Southern India, 8 vols. Madras Government Press: Madras.

TKN: Tirukayilāyan̄ānanaulā, In Cuppiramaṇiyan ed. 2007: 964-68.

TKN: In Patinōrāntirumurai (11 ${ }^{\text {th }}$ Tirumurai), pp. 72-86. Kumarakuruparar Cañkam ed.: Śrīvaikuntam 1972. 
TMK: Tiruvārūrmummanikkōvai, In Cuppiramaṇiyan 2007: 961-64.

TMK: In Patin̄ōrāntirumurai, pp. 60-71. Kumarakuruparar Caṅkam ed.: Śrīvaikuntam 1972.

Tiruvilaiyātậ Purānam of Perumparrapuliyūr Nampi, ed. U. Vē. Cāmpinātaiyar, Chennai 1906/1972.

Upanișads Eight (devanāgarī with English transl.), 2 vols. ed. Svāmi Gambhīrānanda, Advaita Ashrama: Calcutta.

Vasanthakumari, V. 2013. Śrī Śankkara's Bhāsyagranthas: A Synthesis of Science and Spirituality. Sukritīndra Oriental Research Institute: Kochi.

Viṣnusahasranāma 1972, ed. T.M.P. Mahadevan. Bharatita Vidya Bhavan: Bombay.

Wessels-Mevissen, Corinna 2001. The Gods of the Directions in Ancient India. Dietrich Reimer Verlag: Berlin.

Williams, Joanna Gottfried 1983. The Art of Gupta India: Empire and Province. Heritage Publishers: New Delhi.

Zvelebil, Kamil V. 1974. Tamil Literature. Otto Harrassowitz: Wiesbaden. 